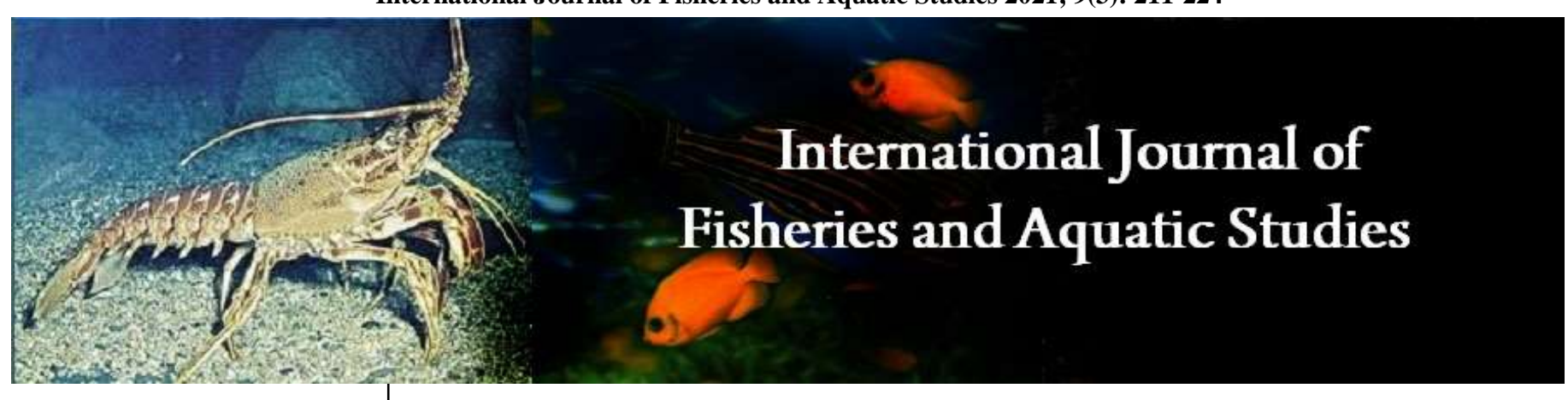

E-ISSN: 2347-5129

P-ISSN: 2394-0506

(ICV-Poland) Impact Value: 5.62

(GIF) Impact Factor: 0.549

IJFAS 2021; 9(3): 211-224

(C) 2021 IJFAS

www.fisheriesjournal.com

Received: 23-03-2021

Accepted: 27-04-2021

\section{Snigdha Dey}

Department of Zoology, Asutosh

College, Kolkata, West Bengal, India

\section{Kamales K Misra}

Department of Zoology, Asutosh College, Kolkata, West Bengal, India

Sumit Homechoudhuri Department of Zoology, University of Calcutta, Kolkata, West Bengal, India
Corresponding Author: Snigdha Dey

Department of Zoology, Asutosh College, Kolkata, West Bengal, India

\section{Gustatory apparatus in the lips and barbel of Mystus tengra (Hamilton, 1822) and Clarias magur (Linnaeus, 1758) from India}

\section{Snigdha Dey, Kamales K Misra and Sumit Homechoudhuri}

DOI: https://doi.org/10.22271/fish.2021.v9.i3c.2485

\begin{abstract}
In this report, the external surface morphology and cellular distribution of taste buds (the primary organ of the gustatory system) of two barbed fishes, Clarias magur (Linnaeus, 1758) and Mystus tengra (Hamilton, 1822) were studied using light microscope, scanning electron microscope and transmission electron microscope. The microscopic analysis reveals that the both type-I and type II TBs are prevalent in both fishes, while a special type-IV TBs is only observed in Mystus tengra. The mucous cells, club cell, pigment cells and lymphocytes are observed alongside with TBs in both species. The upper and lower lips of Clarias magur provided with unculi and microvilli, whereas microridges are found in Mystus tengra. It can be postulated that the differences in distribution and architecture of external taste buds may be connected to differences in their foraging strategies, their microhabitats as well as environmental plasticity throughout their ontogeny in both species and family levels.
\end{abstract}

Keywords: Barbed fishes, taste buds, microscopic analysis, microhabitat, environmental plasticity, polymorphism

\section{Introduction}

Since the bright sunlight is mostly restricted in the aquatic environment, feeding strategy of the fishes is mostly regulated by architecture of their chemosensory system ${ }^{[1]}$. The chemical senses, olfaction and taste play crucial roles in functioning a wide range of activities like feeding, orientation and social behaviour ${ }^{[2]}$. In modern bony fishes (Teleostei), such as Cyprinidae and Siluridae etc, taste buds (TBs) are not confined to the mouth and tongue, but can be seen over the whole anterior body region, frequently concentrated in the epidermal epithelium of the lips and barbels ${ }^{[3-5]}$. Over the years, the cytology of TBs has been studied in various families of fishes ${ }^{[6-9]}$. Feeding strategy, such as prey capture and processing, of fishes depends on their inhabitants (bottom feeders, nocturnal feeder, cave fish or fish living in the deep or foul turbid water) and exhibits improvement of facial lobe corresponding to an unusual number of TBs on the external body surfaces ${ }^{[10,11]}$. Therefore, the allotment of the TBs is alternatively scrutinized either by light microscopy ${ }^{[12]}$ or by electron microscopy ${ }^{[13]}$. For example, Pinky et al. in 2002 reported that upper and lower lips of G. lamta, associated with TBs, help to locate food and trigger pick-up-reflex ${ }^{[14]}$. Further, Tripathi and Mittal in 2012 reported a great number of TBs in the lips of a bottom dwelling fish Noemacheilus botia, which was enhanced due to the darkness and increasing of turbidity in this depth ${ }^{[15]}$. Thus, it can be presumed that the distribution of TBs was reflection of the feeding behavior and the habitat in which the fish live ${ }^{[16-18]}$. For example, for bottom or mud dweller carnivorous barbless fishes the taste buds are present in higher number lip area, while for predatory surface or column feeder carnivores, the density of external taste buds is higher in barbel region than lip area ${ }^{[19]}$. However, the quantitative studies on the densities and differential distribution of external TBs in the lip and barbel area of Indian freshwater fishes are still rare ${ }^{[20]}{ }^{]}$Lacunae still exists in the relationship between the morphology and allocation of external TBs with the environmental parameters as well as predatory strategies. The present work shows the differential distribution of external TBs in two barbed fishes, Clarias magur (Linnaeus, 1758) and Mystus tengra (Hamilton, 1822) in spite of having same habitat. This essentially indicate that the ultrastructure of TBs is might be taxon related as well as species specific. 


\section{Materials and Methods}

Live adult, sex-independent specimens of Mystus tengra (HAMILTON, 1822) and Clarias magur (LINNAEUS, 1758) were collected from the ponds at Baruipur $\left(22^{\circ} 20^{\prime} 58^{\prime \prime}\right.$ $\left.\mathrm{N} / 88^{\circ} 26^{\prime} 21^{\prime \prime} \mathrm{E}\right)$, South-24 parganas, West Bengal, India during the premonsoon period. Fishes were identified in the laboratory by consulting taxonomic books. They were maintained in the laboratory conditions at controlled room temperature $\left(25 \pm 2^{\circ} \mathrm{C}\right)$. Food was given ad libitum during their captivity on alternate days. Average length of the specimen was $7-8 \mathrm{~cm}$ and total weight was measured to the nearest of 2$4 \mathrm{~g}$ using an electronic balance (Sartorius, Model No. BT 223S). After proper acclimatization skin fragments (approximately $3 \times 5 \mathrm{~mm}$ ) were cut from the lip area. Five fishes of each species were sacrificed. Both the lip tissues and barbels were fixed separately in Bouin-Hollande for light microscopy. After routine dehydration in ethanol and embedding in $58^{\circ} \mathrm{C}$ Paraffin, $6 \mu \mathrm{m}$ thick serial sections were prepared. The serial sections were stained in Delafield's haematoxylin and eosin. The observation of serial sections was made under Leitz and Olympus microscopes and photographs were taken in either $10 \times 45$ or $10 \times 100$ magnifications. For scanning electron microscopy, tissues were dissected out and attached sediment and debris was cleaned by heparinized saline (heparin sodium salt $10000 \mathrm{IU}$ mixed in $0.67 \% \mathrm{NaCl}$ solution). Then the tissues were fixed in Karonovsky's fixative $(3 \%$ glutaraldehyde and $2 \%$ paraformaldehyde) for 12 hours at $25-27{ }^{\circ} \mathrm{C}$ in $0.2 \mathrm{M}$ cacodylate buffer ( $\mathrm{pH} 7.2)$. Samples were post fixed in $1 \%$ osmium tetraoxide for 1hour to gain better conductivity in the microscope. After the tissues were dehydrated in an ethanolamyl acetate series the specimen was kept in 100\% amyl acetate in $37^{\circ} \mathrm{C}$ for overnight. The tissues were dried in a critical point drier (POLARON-E-3000) using liquid $\mathrm{CO}_{2}$ for 4 hours. Then tissues were attached to aluminum stubs and were coated with gold in a Sputter-Coater (POLARONSC7620) and examined under scanning electron microscope (Model: FE1-QUANTA 200) operated at $40 \mathrm{kV}$. For transmission electron microscopy, target tissues were fixed in Karnovsky's Fixative $(3 \%$ glutaraldehyde and $2 \%$ Paraformaldehyde) for four hours at $4^{\circ} \mathrm{C}$ temperature in 0.1 M- cacodylate buffer ( $\mathrm{pH}$ 7.2) These were post-osmicated in buffered $2 \%$ osmium tetroxide in distilled water for two hours at room temperature. After dehydration tissues were dehydrated and properly dried and finally embedded in araldite. The ultrathin sections were stained with $0.5 \%$ uranyl acetate and lead citrate and examined under transmission electron microscope (Morgagni 268D; Fei Company, The Netherlands) operated at $80 \mathrm{kV}$ and Tecnai $\mathrm{G}^{2}$; Fei Company, operated at $120 \mathrm{kV}$ with an accelerating voltage.

\section{Results}

Distribution and Architecture of Taste Buds of Clarias magur (Linnaeus, 1758)

\section{a. Light microscopy}

Upper and Lower LIP: The light microscopic images indicate that in the epidermis, epithelial cells are mostly polygonal in shape and at basal layer they are columnar, arranged in a single row resting on the basement membrane (Fig. 1a, 1b and 1c). Along with TBs, four types of epithelial cells (club cells, mucous cells, pigment cells and lymphocytes) are observed in this section (Fig. 1d). Among them, the density distribution of mucous cells and club cells is $40-46 \%$ and $12-15 \%$ respectively. In upper lips, TBIIIs are more frequent than TBIIs (Fig. 2a-2b). The highest density of TBIIIs per unit area is average $52 \mathrm{~mm}^{-2}$ but the density of the TBII is only $23 \mathrm{~mm}^{-2}$ (Fig. 2c). Club cells are found unusually large in size and present as a squeezed form in between the elongated epidermal cells (Fig. 2d-2e). The density distribution of mucous cells and club cells in lower lip is 23$25 \%$ and $10-13 \%$ respectively. Arrangement of other cellular composition is alike as upper lip.

Barbel: In Clarias magur, all the barbels show similar histological structure and they are formed of epidermis and dermis, also stratum germinativum bearing an axial rod (Fig.1e). Relative size of short pair is about $2.2 \%$ of body length and relative size of longer pair is about $5.1 \%$ of body length. In the epidermis, the stratified epithelium consists of polygonal cells while the basal layer is consisting of columnar cells. The epithelium rests on a basement membrane, delimits the epidermis and dermis. In Clarias magur, barbels are mainly rich in two types of TBs, TBI and TBIII. TBIIs are also present but in lower abundance than former two. The size of TBs is about $20-22 \mu \mathrm{m}$ in height and about $10-12 \mu \mathrm{m}$ in width. In proximal part, barbel epidermis is about $130 \mu \mathrm{m}$ thick but in the basal part $1260 \mu \mathrm{m}$ thick. The TBs each embodying with sensory and supporting cells are varied in number in upper, lower and barbel area (Table. 1). Among the epithelial cells, mucous cells are found to be randomly distributed and reached from 10 to $18 \mu \mathrm{m}$ in height and from 8 to $15 \mu \mathrm{m}$ in width.

\section{b. Scanning electron microscopy}

Upper LIP: In upper lip, the plane of the outer surface of epithelia made of mosaic pavement of irregularly polygonal epithelial cells, showed akin typically to that of honeycomb (Fig. 4a). Sensory epithelium provided with both TBII (Fig. 4b) and TBI (Fig. 4c), where TBII is present at the apex of the dome shaped structure. At the near to the apex of the TB, a taste pore and mucus blobbing are present. Small microvilli are prominently projected well above the surface of the epithelia. However, the taste pores of TBI are not clearly visible. At the distal region of the upper lip surface, the architecture of the epithelia gradually gets transformed into truncated polygonal (unculi) like structure with slight concavity in the central region (Fig. 4d).

Lower LIP: The sensory epithelium of lower lip is interspersed by mucogenic islands with openings of the TBIII (Fig. 4e). Outer epithelium is covered with a dense carpet of microvilli (Fig. 4f). The tuft of microvilli looked like a round knob like structure when viewed from the top. The density of the microvilli is $23-25 \mathrm{~mm}^{-2}$. The most conspicuous surface feature of the epithelia with cluster of microvilli is the presence of wavelike pattern. Aggregation of TBII in sensory epithelium is interspersed by mucogenic area (Fig. 4g).

Barbel: All the barbs have very similar surface topography. The sensory area shows wave-like pattern with extensive network of microvilli, separated by distinct furrows like crater (Fig. 5a). Mucous cell openings are seen as blobs of mucus, are intermingled with the microvilli. The supolyrface separated by concave depressions of varied depth at regular interval. Tall and straight sensory protrusion, perpendicularly erected, is found. This may be representing the cupula of the superficial neuromast (Fig. 5b). Each TB is characterized by these closely packed microvilli. At the higher magnification 
(x24000) two set of microvilli are clearly seen (Fig. 5c). Larger microvilli are caterpillar like, are appear to taper at their ends. Small microvilli are characterized by club shaped blunt tips and some are tennis-racket like structure (Fig.5d). The smaller microvilli appeared to constitute the major fraction (Fig. 5e). The epithelial surface of the nasal barbel is organized into irregular extensive folding, separated by gutter like depression. On the surface of irregular ridges in the outer epithelia TB openings are sporadically distributed. These openings may be the represent presence of TBIII, lying below the level of the general surface of the epithelium, arranged in a whirl like pattern (Fig. 5f).

\section{c. Transmission electron microscopy}

Upper LIP: In the epithelium, both light and dark cell contribute to the receptor area by their apical receptor villi (Fig. 8a). Electron dense core vesicles and secretory granule are present near the receptor area (Fig. 8b). The basal layer of the epidermis consists of elongated cells with pointed apices, these cells are attached to the basal lamina. Nuclei of the basal epidermal cells are generally oval-shaped with a slightly irregular outline (Fig. 8c). Mucus cells are consisting of mucus droplets near the vicinity of the Golgi apparatus, free ribosome, lysosome like dense bodies and electron dense ovoid bodies (Fig. 8d-8e). The myelinated nerve fibres are very prominent near the receptor area (Fig. 8f).

Lower LIP: TBs are small, pear-shaped, intraepithelial, vertically oriented sensory organs, found on lower lip. The taste-buds contain a maximum of four morphologically distinct cell types, not all of which, however, are to be distinguished regularly. At the periphery of the buds oval shaped cells occur which are in many respects intermediate between the normal epidermal cells and the central bud cells. (Fig. 9a). In the centre of the bud is occupied by two small cell types differ in electron density, both of which reach the surface of the epidermis, where they bear a few relatively thin microvilli. As the two cell types differ in the density of their cytoplasm and may be called "light" and "dark" cells. The light cells are wrapped on the outer face. The nucleuses of the dark cells are ovoid and contain much dense chromatin (Fig. 9b). Between the dark and light cells and near the basal lamina, the basal cells horizontally present (Fig. 9c). The most prominent organelles of the TB cells are a large nucleus, semi-oval or elliptical mitochondria and abundant rER with polyribosome (Fig. 9d). The cisterns of rER occur mainly in a lateral position of the nucleus; the extended Golgi field is to be found lateral to the nucleus, and is surrounded by a multitude of clear vesicles. The most striking character of marginal cells is perinuclear systems of smooth endoplasmic reticulum and vertically oriented microtubules (Fig. 10a). Copious smooth surfaced tubules in a light receptor cell are seen in supranuclear position (Fig. 10b). In epithelial cells small membrane-bound electron-dense granules are present (Fig. 10c). Tight junctions are located immediately underneath the level of the receptor area and, approximately further down, desmosomes (zonulae adherences) occur, nerve endings also found near this area (Figs. 10d-10e). The plasma lemmas of the sensory cells are tightly interdigitated with each other in close proximity (Fig.10f).

Barbel: Arrangement of the dark and light cells with clear vesicles is arranged at the receptor area (Fig. 11a). In perinuclear position, dark and light bands present are very rich in microtubules and endoplasmic reticulum. Parallel array of tonofilaments arranged near the nucleus. The vesicles are in close association with the Golgi apparatus. Two types of vesicles occur in the synaptic area: small clear vesicles (8$12 \mathrm{~nm}$ in the mean diameter) and dense-cored vesicles (Fig. 11b). Myelinated nerve fibre is prominent in synaptic region, whereas the outer receptor areas are filled with numerous microvilli (Fig. 11c). Clear vesicles ensheath the nerve endings form a nerve plexus at near the basal membrane (Fig.11d). The light cell has round mitochondria with tubular cristae and lucid matrix and well-developed Golgi system in the supranuclear region. Membrane bounded vesicles (0.04$0.10 \mathrm{gm}$ in diameter), irregular elongated sacs (up to $0.5 \mathrm{gm}$ long), and tubular sacs expanded at the end of cell periphery. Some light cells contain predominantly irregular, clear vesicles and others contain smaller, denser ones. Together, the vesicles, saccules and tubules appear which may be a part of granular ER (Fig.11e).

\section{Distribution and Architecture of Taste Buds Mystus tengra (Hamilton, 1822) \\ a. Light microscopy}

Upper LIP and Lower LIP The lip integument comprises three main layers- epidermis, dermis and subcutis. The epidermis and dermis are separated by a basement membrane, which follows the depressions and elevations of the upper surface of the dermis (Fig. 3a). The epidermis is further divided into three layers, such as outermost epithelial, middle and basal layer (germinativum layer). The stratum germinativum layer is composed of a single layer of cuboidal cells. In between the cuboidal cells, there are small oval or round lymphatic spaces, which contain lymphocytes with deeply stained nuclei. The middle layer of the epidermis is composed of elongated epithelial cells with oval or spherical nuclei. In between these elongated cells, we found mucous and club cells which are differ in number in upper and lower lips (Table 1). The club cells are restricted mainly in the middle layer of the epidermis of the upper lip area. The density of the club cells is more in the epidermis of Mystus is greater than that in C. magur. TBs are present in both lips predominantly two types, TBII and TBIII (Table 2). TBIV, which is placed underneath of the level of middle epithelial layer, but fewer in number than other three category. The dermis consists of relatively thick outer loose connective tissue layer (stratum laxum). The loose connective tissue layer situated below the basement membrane is richly supplied with blood capillaries and nerve fibre.

Barbel In Mystus tengra, the histological transactions show that all the barbels have identical microscopic constituents as found in Clarias magur. TBII and TBIII are mostly prevalent among the four types of TBs. TBIV also identified in Mystus tengra. Conspicuous round small club cells are inadequately present in Mystus tengra. They are generally buried in the middle layer of the epidermis (Fig. 3b-3f).

\section{b. Scanning electron microscopy}

Upper LIP The upper lips are characterized by a great number of linear compressed fringes with ovoid structure (Fig. 6a). The sensory epithelia are also provided with TBI types (Fig. 6b). Fine parallel folds of microridges with numerous capillary networks with interconnections are also identified (Fig. 6c). 
Lower LIP Surface architecture is same as upper lip. In some sensory area, Hexagonal epithelial cells with properly demarcated boundary and TBIII opening in concave surface are found (Fig. 6d). TBII is also present with ovoid taste pore opening, $8 \mu \mathrm{m}$ in diameter (Fig. 6e).

Barbel The base of the barbel is devoid of TBs. TBI is situated on epithelial hillocks surrounded by the network of microridges (Fig. 7a). The apex of the TB is characterized by small microvilli like sensory processes above the cell surfaces. Mucin particles are prominent (Fig. 7b). TBII is slightly broader in base than TBI and less exposed above the epithelium (Figs. 7c, 7d and 7e). Proper boundary of the TBs is not resolved since several of the flat shaped bulging structure is present which might be debris. A few closed types TBIII are observed, which are not protruding above the surrounding epithelium (Fig. 7f). The sensory epithelium has several leaves like epithelial projection, rounded apically and borderline is fringed. These stumpy epithelial projections denote the presence of TBIV, moderate in number. In this species, TBIV found at the tip of the maxillary barbel. Higher magnification SEM illustrates, that each TBIV are situated in the inner core of these distinct microplicae (elevated ridges) (Fig. 7g). The density of the TBs in the barbel area is near 55$60 \mathrm{~mm}^{-2}$.

\section{c. Transmission electron microscopy}

Upper LIP In the epithelium, both light and dark cells are found along with dcv cells (Fig. 12a). In the receptor cells, the oval-shaped nuclei are found with rER and dark secretory vesicular body near the edge of nucleus (Fig. 12b). With respect to electron density, the difference between dark and light cells is not very pronounced. Light and dark cells form functional area with the basal lamina, and contain huge number of mitochondria and rough endoplasmic reticulum (rER)(Fig. 12c). The most chief organelles of the primordial TB cells are a large nucleus, tubular large mitochondria and abundant polyribosome (Fig. 13d). Electron dense small vesicles are scattered in the cytoplasm. Both light and dark cells contain parallelly arranged rER, intermediate filaments arranged in bundles. Active nucleus with prominent nucleolus is present in the light cells (Fig. 12e). Spindle shaped mitochondria generally present in the periphery of the nucleus (Fig. 12f). Basically, the light cells terminate as vesicle containing processes which are frequently adjacent to the surface of a basal cell. Three to five basal cells adjacent to and parallel with the basal lamina are present in each TB.

Lower LIP In the lower lip, the arrangement of light and dark cells in the TBs is identical with the upper lip, though their number varies. Apart from the typical gustatory and basal cells, degenerating cells are present (Fig. 13a). They are individualized by high occurrence of lysosome. Mucus secretory cells show round active nucleus (Fig. 13b), where nuclear envelope is covered by tubular mitochondria. The sER is found at the periplasmic area of the cells. Dense core vesicle filled cells are also present. Golgi bodies in dark cells are present in perinuclear position (Fig. 13c). The dimensions of the light cells are similar to those of the dark cells, but the nucleus of the light cell is distinctive. Light cell contains a band of filamentous material often arranged as a closed ring near the nucleus. In dark cell, nucleoli are rare, whereas in the light cell nucleoli are of $0.5-1 \mu \mathrm{m}$ in diameter. In both cases, the cell nucleus has an irregular contour, often with a broad and but not deep notch (Fig. 13d). The basal cells contain ribosome, occasional saccules of sER, and glycogen particles. Small vesicles about $60 \mathrm{~nm}$ in diameter occur in large clusters, generally in the superior half of the cell. These vesicles are sometimes grouped near the periphery of the basal cell where there is contact with a nerve fibre, in configurations which resemble synapses. A few dense-cored vesicles are present in the basal cell. Between the basal cells, and the dark and light cells, a large number of closely packed unmyelinated nerve fibres, Tonofilaments are seen (Figs. 13e and 13f).

Barbel The sensory cells of the barbels are same as Clarius batrachus. In the synapse area, fibrocytes are present with sensory projections in extracellular matrix. The synaptic region prominent with nerve endings (Fig. 14a). In the synapse area containing many synaptic vesicles and dendrite containing neurofilament. Bunch of myelinated axons are found in these regions (Figs. 14b and 14c). Many nerve fascicles having Schwan cells and nerve axon complexes are also prominent (Figs. 14d and 14e). The distributions of different cell types in taste buds of two selected fishes have been shown in Table 3.

\section{Discussions}

In these selected teleost fishes, in addition to the three types of TB (Types I-III), a fourth type (TB IV) comprising of very small buds is found in Mystus tengra. The TBIV is dispersed solitary and levelled with the epithelial surface, encircled by a thick ring of epithelial cells. At the summit of each TB, closely packed microvilli are observed. These microvilli appear to represent the taste hair originating from the sensory cells of the TBs. The disparity in the total number of TB and their allocation in the lips and barbels may be indicating the possible divergent mechanisms of foraging and foodrecognition in the water column. The projected TBs (type I and II) may be the first to come in contact with the surface water and enable the fish to sense the nature of food available in a particular feeding zone before it opens mouth to gulf in large quantities of water along with available food particles [21]. This opinion substantiates with Singh and Bisht (2014), who analyzed the structure of the lip epidermis by SEM in the Hill stream fishes in Almora District Rivers in Kumaun region ${ }^{[22]}$.

McCormick in 1993 found that food availability influences the relationship between barbel length and fish size in tropical goat fish Upen eustragula (Mallidae) ${ }^{[23]}$. Generally, slower growing fishes possess longer barbels relative to their body length. Therefore, the presence of four pairs of barbels in $C$. magur and $M$. tengra, despite of being moderately growing fish, indicates their strong gustatory ability in searching food at the bottom as well as water column. In both the species, TBs are extensively distributed in the outer surface of the barbels than lips. The density of TBs is amplified gradually from basal to the apical end of each barbel. The densities of TB are higher in the maxillary and the inner mandibular barbels than in the outer mandibular and nasal ones. These findings are similar with the results of Malupterus electricus, but inconsistent with the Clarias lazera, where TBs are absent in the inner mandibular and the nasal barbel ${ }^{[24]}$. In-Seok et al. in 2012 stated that the barbel, by means of TBs, can effectively guide the fish towards source of food even in the complete absence olfactory response by the olfactory rosette ${ }^{[25]}$. On the other hand, in between C. magur and M. tengra, 
density of the TBs is higher in the former one. In C. magur, the presence of higher number of TBs can be considered as an adaptation to its bottom dwelling and sluggish feeding behavior; compensating for the restricted visibility in the foul turbid water where it inhabits. The decision is made when contact of food with TBs results into a mechanical impulse perceived and transmitted from the sensory cells to the brain centers ${ }^{[26]}$. In case of Clarius, the touch seems important for triggering the feeding reflex as vision is only of limited use. As a consequence, TBIII found to be higher number in Clarius than Mystus, which is mainly involved for chemoreception. Furthermore, presence of a greater number of TBI at the summit of the conspicuous epithelial protrusions may enhance the probability of contact between the receptors and the food items in the muddy water. TBI may be superior for the perception of tactile stimuli for Clarius species. Ahmed et al. (1993) also have reported that carnivorous Mystus tengra is neither a true surface feeder nor a true bottom feeder; rather its food substances are distributed throughout the different layers of the water bodies. ${ }^{[27]}$ As a result, this species needs both chemo and mechano reception simultaneously. Therefore, they contain higher number of TBII to meet the physical demand. Similar consequences are reported by Boudriot and Reutter (2001), who described that the cave-dwelling Astyanax jordani, which has lost its vision, has a larger number and a more extensive distribution of external TBs in the barbels' surface than the barbels of riverdwelling Astyanax mexicanus which has normal vision. ${ }^{[28]} \mathrm{A}$ similar observation has been made by scientists in case of other species as well ${ }^{[29-31]}$. The greater density and number of TBs are generally associated with a greater sensitivity to chemical stimuli. From the present findings, it can be concluded that, there is a compensatory relationship between TB distributions with the reduction of the vision which occurs in muddy and/or deeper water.

Similarly, in both fishes, the longitudinal sections through the TBs show that the nuclei of dark cells lie at the half of the bud but in light cells at a deeper level. A similar observation was made by Grover-Johnson and Farbman et al. for Catfish, lctalurus punctatus ${ }^{[32]}$. Zuwala and Jakubowski (1993) noted the occurrence of hemidesmosomes (joining the cell with the basement membrane) and a relatively large quantity of tonofilaments are the most suitable criteria for identifying the supporting cells ${ }^{[33]}$. Present findings corroborate with this recommendation. The dcv-cells of TBs can be the subtype of light cells as observed for TBs of other teleostean ${ }^{[34]}$. These teleostean basal cells may be interpreted as interneuron since numerous synaptic interconnections between light cells and basal cells as well as between basal cells and axons is found in the present study ${ }^{[35]}$.

In Mystus tengra, the surface architecture is characterized by micro-ridges. As Mystus tengra is also planktonic browser in habit, the microridges are likely to be involved in a variety of functions e.g., absorptive or secretory activities or to aid in laminar flow ${ }^{[36]}$. On the other hand, upper lip and lower lip of C. magur are found to be keratinized. The surface of the epithelial cells in these regions is transformed to form single modified cell, the unculi. In C. magur, this structure may be related with their omnivorous bottom feeding habit and may be considered to facilitate clinging or adherence of the fish to the surface of rocks or stones [37]. According to Agrawal and Mittal (1992), this structure provides sharp cutting edge on the upper lip, as found in the Cirrhina mrigala ${ }^{[38]}$. Similarly, as a bottom dwelling fish, the presence of neuromast in the barbel of $C$. magur may help to browse on the shallow bottom and margins and take vegetable debris, insects, worms, planktonic algae etc. ${ }^{[39]}$

In these fishes, lip and barbel epidermis is characterized by large number of unicellular secretory glands, i.e., mucous cells, uninucleate club cells, interspersed between the epithelial cells and TBs. The large numbers of mucous cells in these fishes may be an adaptation due to their peculiar bottom-scooping habit. The main mucus secretory cells in the selected fishes aggregated in different areas of lip and barbels, formulating multicellular holocrine glands ${ }^{[40,41]}$. Similarly, the club cells can be associated with primary immune response for invading pathogens, penetrating parasites ${ }^{[42]}$. Also, the presence of the eosinophilic club cells of fishes has been of major attention to evolutionary ecologists since the discharge of the mediator alarm response is under involuntary control and does not takes place unless the fish is wounded. ${ }^{[43]}$ Generally. The number of lymphocytes in the epidermis in tropical species is in higher than in temperate fish. The pigment cells above the dermal layers may be amalgamating with the lip color with that of the substratum in the dark muddy bottom ${ }^{[44]}$.

Table 1: Differential distribution TBs with other gustatory cell types in the sensory epithelium of upper lip (UL), lower lip (LL) area and barbels (BL) of two selected fish species in the present study (values represent in percent calculation).

\begin{tabular}{|c|c|c|c|c|c|c|c|c|c|c|c|c|c|c|c|}
\hline \multirow[t]{2}{*}{ Species name } & \multicolumn{3}{|c|}{ TBs } & \multicolumn{3}{|c|}{ Mucous cells } & \multicolumn{3}{|c|}{ Club cells } & \multicolumn{3}{|c|}{ Lymphocytes } & \multicolumn{3}{|c|}{ Pigment cells } \\
\hline & UL & LL & $\mathrm{BL}$ & UL & LL & $\mathrm{BL}$ & UL & LL & $\mathrm{BL}$ & UL & LL & $\mathrm{BL}$ & UL & LL & BL \\
\hline $\begin{array}{l}\text { Clarius } \\
\text { magur }\end{array}$ & $21-23$ & $18-21$ & $45-46$ & $15-16$ & $14-16$ & $1-2$ & $20-22$ & $6-9$ & - & $4-9$ & $7-9$ & $3-4$ & $20-21$ & $9-11$ & $2-3$ \\
\hline $\begin{array}{l}\text { Mystus } \\
\text { tengra }\end{array}$ & $18-19$ & $23-25$ & $45-48$ & $12-13$ & $12-14$ & $1-2$ & $21-22$ & $5-7$ & $1-2$ & $5-6$ & $8-12$ & - & $10-11$ & $5-9$ & - \\
\hline
\end{tabular}

Table 2: Differential distribution of TBI, TBII, TBIII and TBIV (average) per unit area (TBs $\mathrm{mm}^{-2}$ ) in the sensory epithelium of upper lip (UL), lower lip (LL) area and barbels (BL) of two selected fish species in the present study (values represent in percent calculation).

\begin{tabular}{|c|c|c|c|c|c|c|c|c|c|c|c|c|}
\hline \multirow{2}{*}{ Species name } & \multicolumn{3}{|c|}{ TBI } & \multicolumn{3}{|c|}{ TBII } & \multicolumn{3}{|c|}{ TBIII } & \multicolumn{3}{|c|}{ TBIV } \\
\hline & UL & LL & $\mathrm{BL}$ & UL & LL & $\mathrm{BL}$ & UL & LL & $\mathrm{BL}$ & UL & LL & $\mathrm{BL}$ \\
\hline $\begin{array}{l}\text { Clarias } \\
\text { magur }\end{array}$ & $8-9$ & $9-11$ & $17-18$ & $8-11$ & $7-10$ & $11-13$ & $2-3$ & $1-6$ & $15-19$ & - & - & - \\
\hline $\begin{array}{l}\text { Mystus } \\
\text { tengra }\end{array}$ & $5-6$ & $9-10$ & $3-5$ & $12-13$ & $9-11$ & $20-22$ & 4-6 & $5-6$ & $13-16$ & $4-6$ & $5-8$ & $6-9$ \\
\hline
\end{tabular}


Table 3: Cell types in TBs of sensory epithelium in the upper and lower lip area and also in the barbel of the two selected fish species of the present study (The numbers of TBs cells are counted in five transversally cut TBs; basal cells are counted in longitudinal sections of 10 TBs).

\begin{tabular}{|c|c|c|c|c|c|}
\hline Species name & $\begin{array}{c}\text { Light Cells } \\
\text { Number per TB }\end{array}$ & $\begin{array}{c}\text { Dark Cells } \\
\text { Number per TB }\end{array}$ & $\begin{array}{c}\text { Basal Cells } \\
\text { number per TB }\end{array}$ & $\begin{array}{c}\text { Dense-core vesicle Cells } \\
\text { number per TB }\end{array}$ & $\begin{array}{c}\text { Degenerating Cells } \\
\text { number per TB }\end{array}$ \\
\hline $\begin{array}{c}\text { Clarias } \\
\text { magur }\end{array}$ & $25-31$ & $12-13$ & $3-5$ & $5-8$ & $2-6$ \\
\hline $\begin{array}{c}\text { Mystus } \\
\text { tengra }\end{array}$ & $32-33$ & $13-16$ & $3-5$ & $2-5$ & $0-3$ \\
\hline \hline
\end{tabular}

\section{Photomicrographs of Light microscopy of Clarias magur}

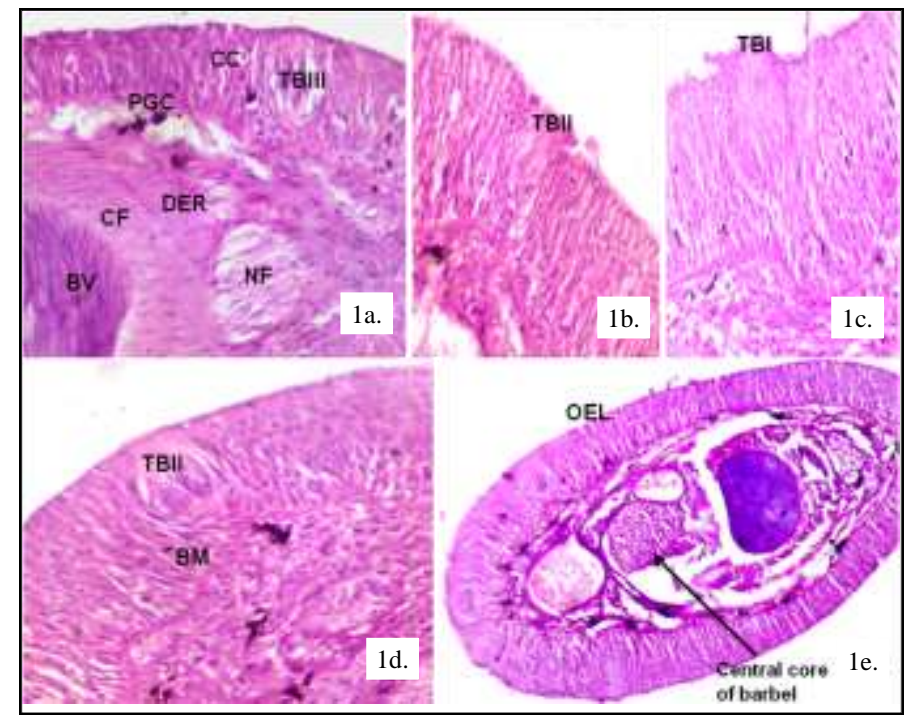

Fig 1: (a) A photomicrograph of a vertical section at the skin of upper lip of Clarias magur showing thick epidermis of stratified squamous epithelium with club cells (CC), mucous cells (MC), aggregated pigment cells (PGC) and lymphocytes (LYC) and dermis with collagen fibers (CLF), Nerve fibres and blood vessels (BV) (H\&E,10X). (b) A photomicrograph of a vertical section at the skin of lower lip of Clarias magur showing TBII is placed underneath of epithelial layer (H\&E, 40X). (c) A photomicrograph of a vertical section at the skin of upper lip of Clarias magur showing TBI (H\&E, 40X). (d) A photomicrograph of a vertical section at the skin of upper lip of Clarias magur showing TBII is slightly elevated toward the exterior of epithelium with basal cells (BC), light cells (lC) and supportive cells (Sup.C) (H\&E, 40X). (e) A

photomicrograph of a vertical section at the barbel area of Clarias magur showing TBs is present at the exterior of epithelium with basal membrane $(\mathrm{BM})$, with the central core of the barbel (H\&E, 10X).

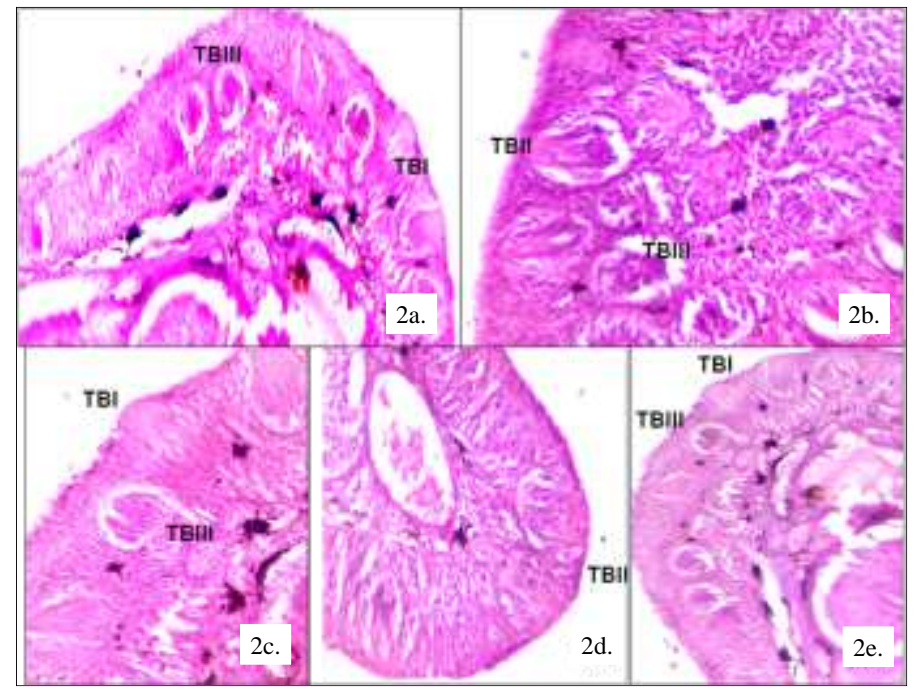

Fig 2: (a) A photomicrograph of a vertical section at the skin of maxillary barbel of Clarias magur showing thick epidermis of stratified squamous epithelium with TBI, TBII with also TBIII, aggregated pigment cells (PGC) and lymphocytes (LYC); dermis with collagen fibers (CLF) and blood vessels (BVs) (H\&E,40X). (b) A photomicrograph of a vertical section at the skin of another distal part of maxillary barbel of Clarias magur showing thick epidermis of stratified squamous epithelium with TBII, TBIII, aggregated under the outer epithelial layer (H\&E, 40X). (c) A photomicrograph of a vertical section at the skin of outer mandibular barbel of Clarias magur showing thick epidermis with TBI and TBIII- placed under the outer epithelial layer (H\&E, 40X). (d) A photomicrograph of a vertical section at the skin of inner mandibular barbel of

Clarias magur showing thick epidermis with TBII - placed under the outer epithelial layer (H\&E, 40X). (e) A photomicrograph of a vertical section at the skin of nasal barbel of Clarias magur showing thick epidermis with TBI and TBIII - placed under the outer epithelial layer (H\&E, 


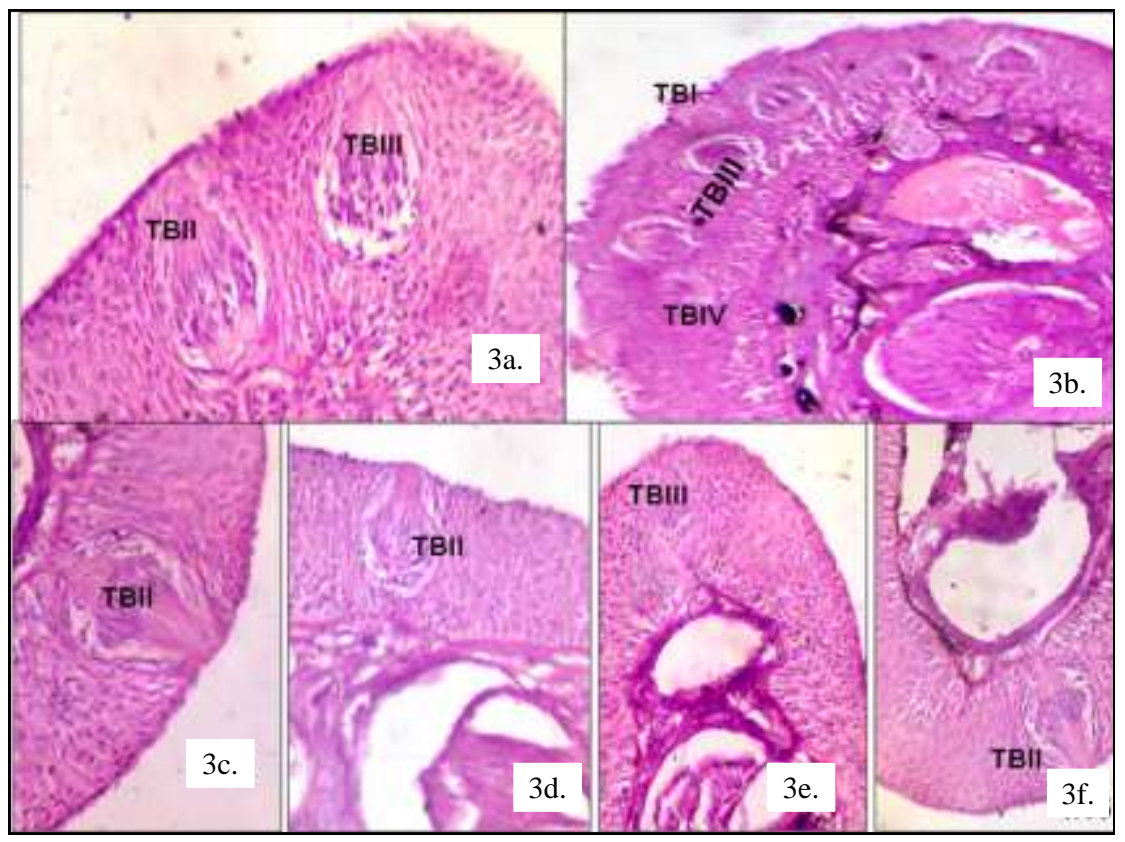

Fig 3(a): A photomicrograph of a vertical section at the skin of upper and lower lip of Mystus tengra showing thick epidermis of stratified squamous epithelium with TBII and TBIII cells (BV) (H\&E,40X). Other cellular architecture and arrangement same as Clarias magur though the number of the cell types vary. (b) A photomicrograph of a vertical section of barbel of Mystus tengra showing TBI and TBIII with TBIV which is placed underneath of middle epithelial layer (H\&E, 40X). (c) A Photomicrograph of a vertical section at the skin of maxillary barbel of Mystus tengra showing TBII just underneath of epithelial layer (H\&E, 40X). (d) A photomicrograph of a vertical section at the skin of outer mandibular barbel of Mystus tengra showing TBII just underneath of epithelial layer (H\&E, 40X). (e) A photomicrograph of a vertical section at the skin of nasal barbel of Mystus tengra showing TBIII which is placed underneath of the outer epithelial layer (H\&E, 40X). (f) A photomicrograph of a vertical section at the skin of inner mandibular barbel of Mystus tengra showing TBII just underneath of epithelial layer (H\&E, 40X).

\section{Photomicrographs of scanning electron microscopy of Clarias magur}

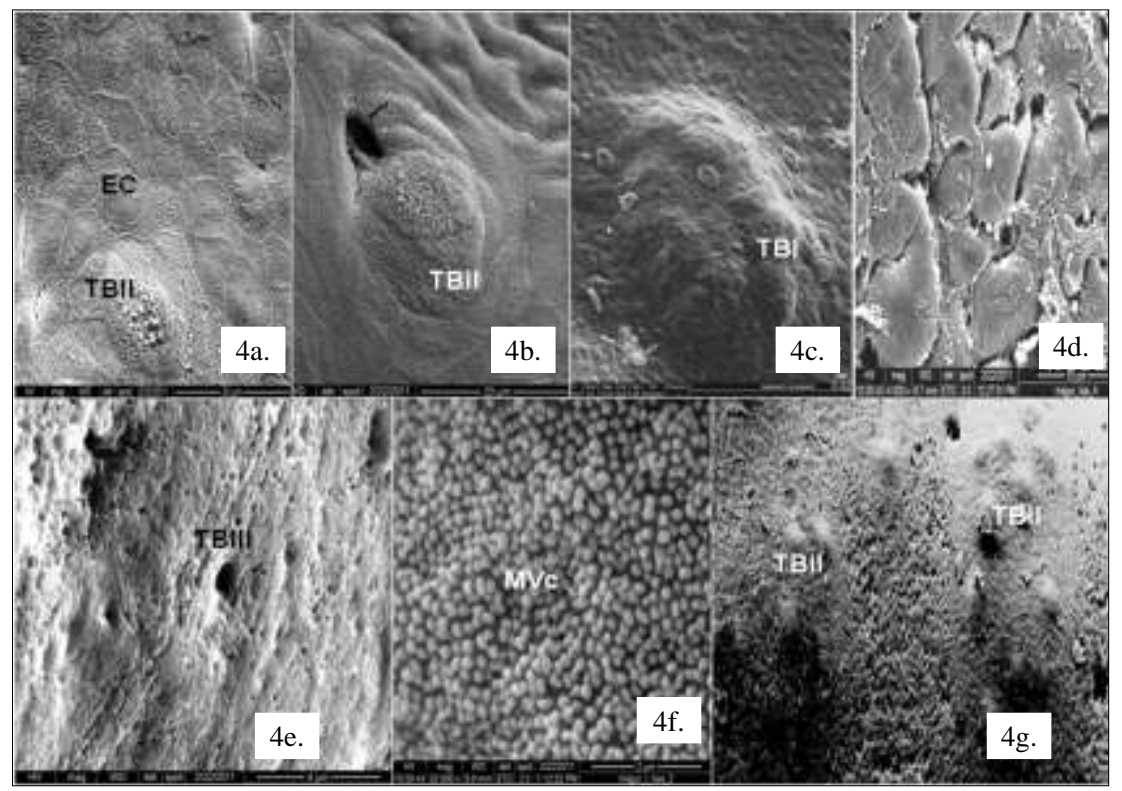

Fig 4: (a) Scanning electron micrograph of the upper lip of Clarias magur showing sensory epithelium with TBII. (b) Scanning electron micrograph of the upper lip of Clarias magur showing Small Island of mucus cells and TBII with taste pore opening. (c) Scanning electron micrograph of the upper lip of Clarias magur showing that epithelial cells with TBI. (d) Scanning electron micrograph of the upper lip of Clarias magur showing surface architecture of the epithelia with polygonal unculi like structure. (e) Scanning electron micrograph of the lower lip of Clarias magur showing taste pore of TBIII and mucogenic area in sensory epithelium. (f) Scanning electron micrograph of the lower lip of Clarias magur showing small stumpy microvilli with MVC cells. (g) Scanning electron micrograph of the lower lip of Clarias magur showing aggregation of TBII in sensory epithelium which is interspersed by mucogenic area. 


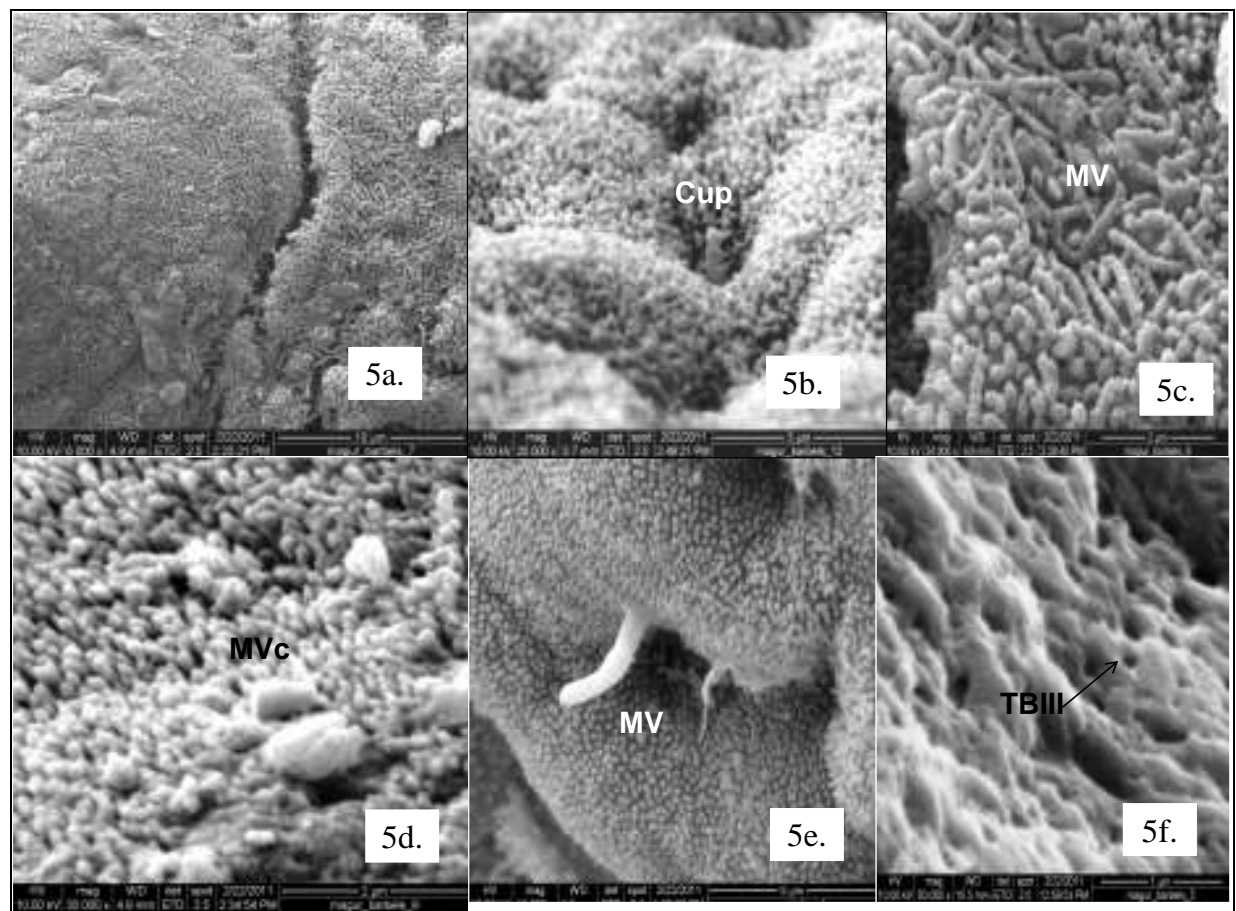

Fig 5: (a) Scanning electron micrograph of the barbel of Clarias magur showing wave-like pattern with extensive network of microvilli and sensory area is separated by distinct spaces. (b) Scanning electron micrograph of the barbel of Clarias magur showing Small Island of mucus cells with TBIII pore opening and cupula of the neuromast organ. (c) Scanning electron micrograph of the barbel of Clarias magur showing that adjacent epithelial cells appear as polyhedral plaques and demarcated by uniform well-defined many rows of microvilli. (d) Scanning electron micrograph of the barbel of Clarias magur showing microvilli forming a pattern and in between the whirl, varied dimension mucus droplets are seen. (e) Scanning electron micrograph of the barbel of Clarias magur showing that adjacent epithelial cells appear as polyhedral epidermal elevations with longer types of microvilli. (f) Scanning electron micrograph of the nasal barbel of Clarias magur showing a whirl like pattern and in between the whirl of the small ridges, TBIII are seen.

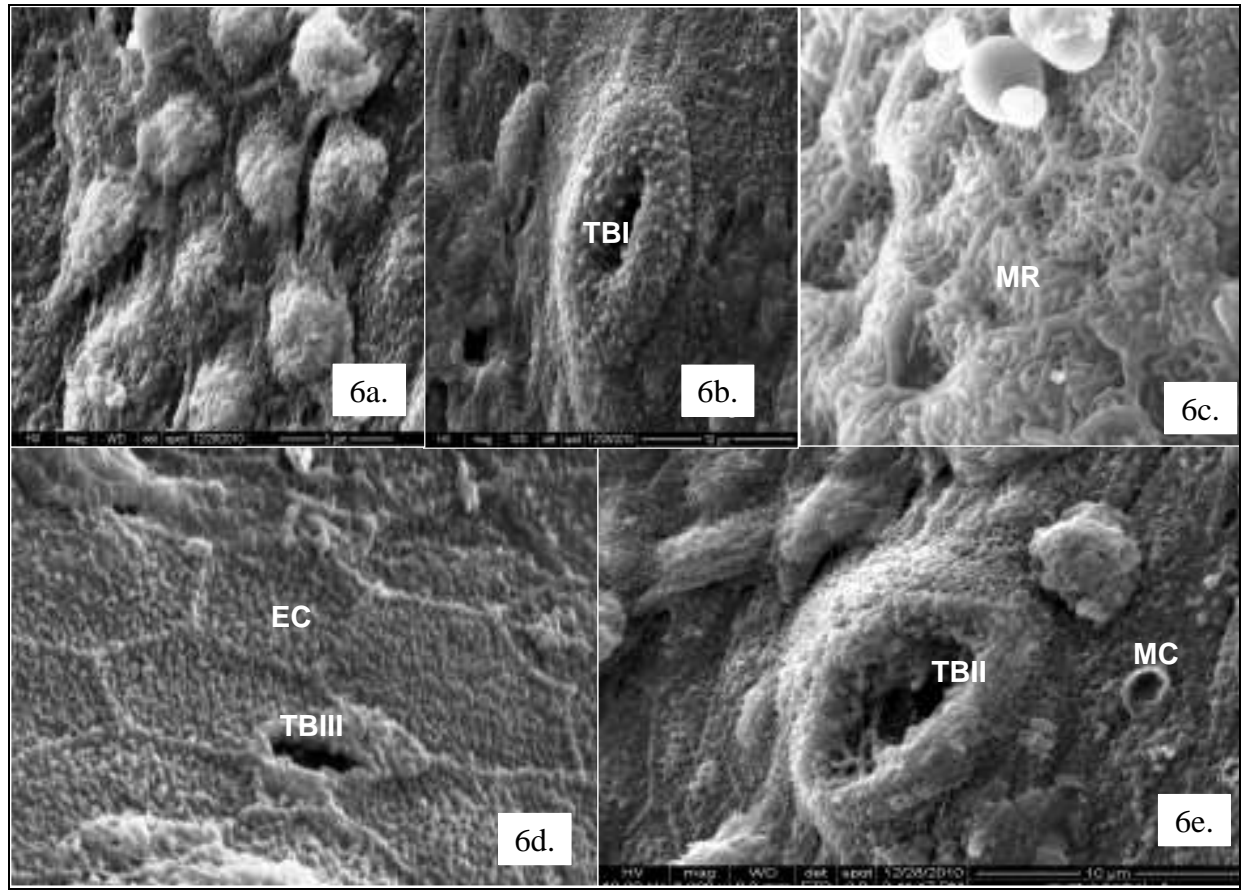

Fig 6: (a) Scanning electron micrograph of the upper lip of Mystus tengra showing wave-like pattern with extensive network of microridges and separated by distinct spaces. (b) Scanning electron micrograph of the upper lip of Mystus tengra showing Small Island of mucus cells with TBIII

pore opening. (c) Scanning electron micrograph of the upper lip of Mystus tengra showing that adjacent epithelial cells appear as capillary network of microridges (MR) and demarcated by uniform well-defined interconnected double rows ridges. (d) Scanning electron micrograph of the lower lip of Mystus tengra showing epithelial cells with varied dimension and TBIII are seen. (e) Scanning electron micrograph of the lower lip of Mystus tengra showing distinct TBII. 


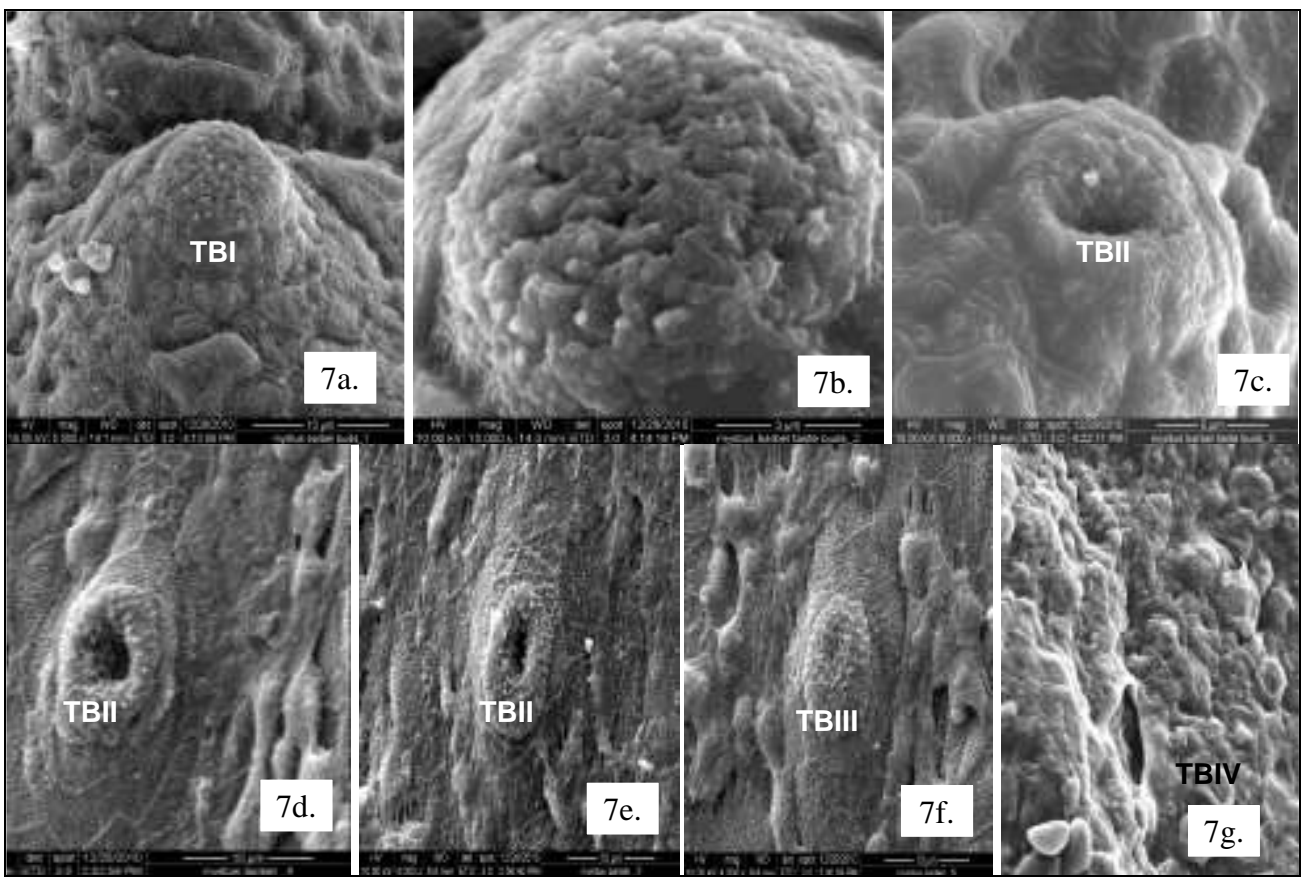

Fig 7: (a) Scanning electron micrograph of the barbel of Mystus tengra showing TBI. (b) Scanning electron micrograph of the barbel of Mystus tengra showing Small Island of taste pores intermingled with mucus cells in the TBI pore opening. (c) Scanning electron micrograph of the barbel of Mystus tengra showing TBII surrounded by ununiform well-defined rows of microridges. (d) Scanning electron micrograph of the barbel of Mystus tengra showing mucus cells and TBII. (e) Scanning electron micrograph of the barbel of Mystus tengra showing that adjacent epithelial cells appear as polyhedral epidermal plaques and TBII. (f) Scanning electron micrograph of the barbel of Mystus tengra showing microridges with TBIII are seen. (g) Scanning electron micrograph of the barbel of Mystus tengra showing microridges with TBIV are seen.

\section{Photo micrograph of transmission electron microscopy of Clarias magur}

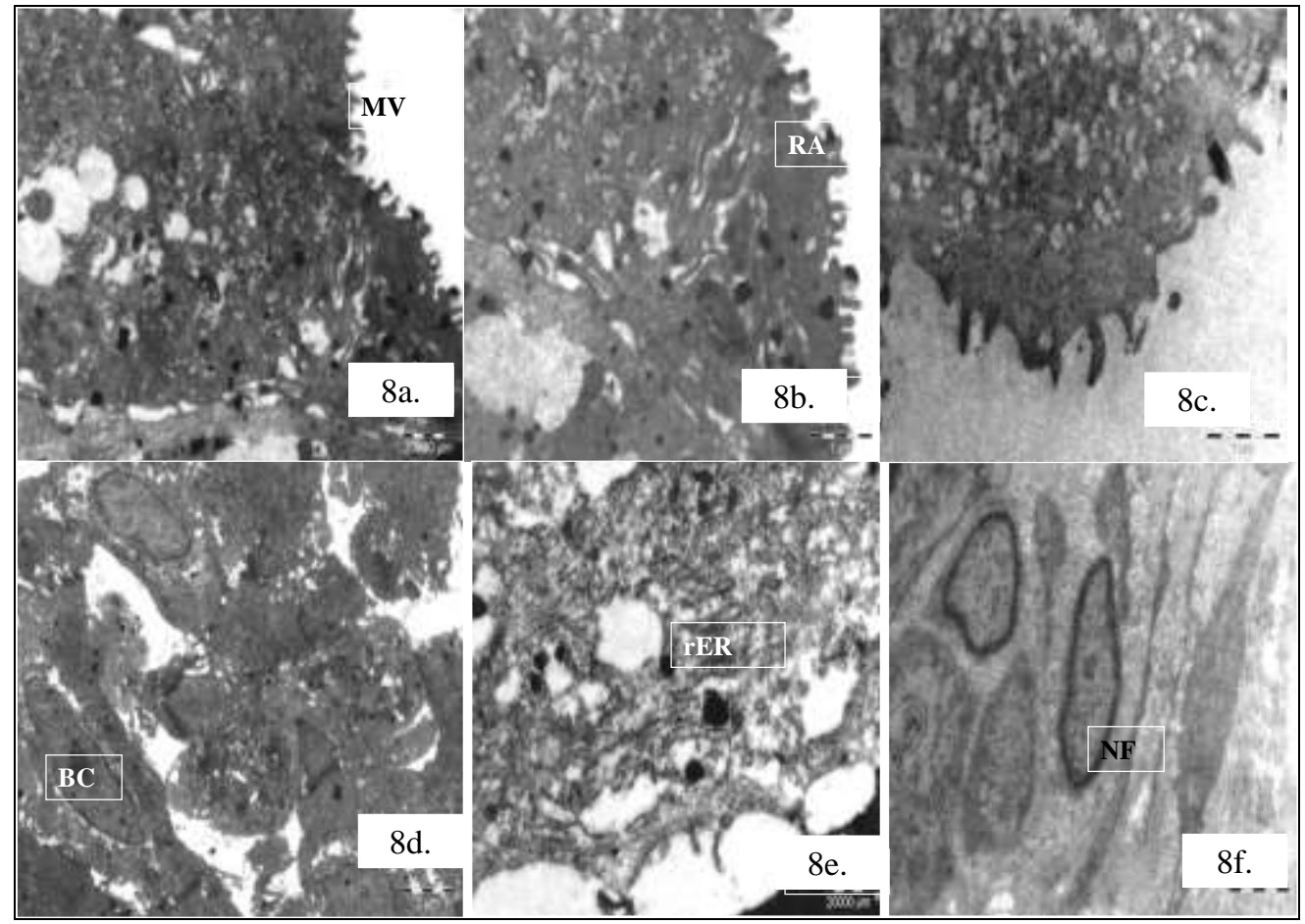

Fig 8(a): Transmission electron micrograph of upper lip of Clarias magur showing apical region of a taste buds. Both light and dark cell contribute to the receptor area by their apical receptor villi. (b. c) Transmission electron micrograph of upper lip of Clarias magur showing electron dense core vesicles near the apical area. (d) Transmission electron micrograph of upper lip of Clarias magur showing cellular pattern in slender basal cells where both sides are tapering. (e) Transmission electron micrograph of upper lip of Clarias magur showing intracellular composition of mucus cells. (f) Transmission electron micrograph of upper lip of Clarias magur showing cut end of axons in myelinated nerve fibers at the junction near the basal cells. 


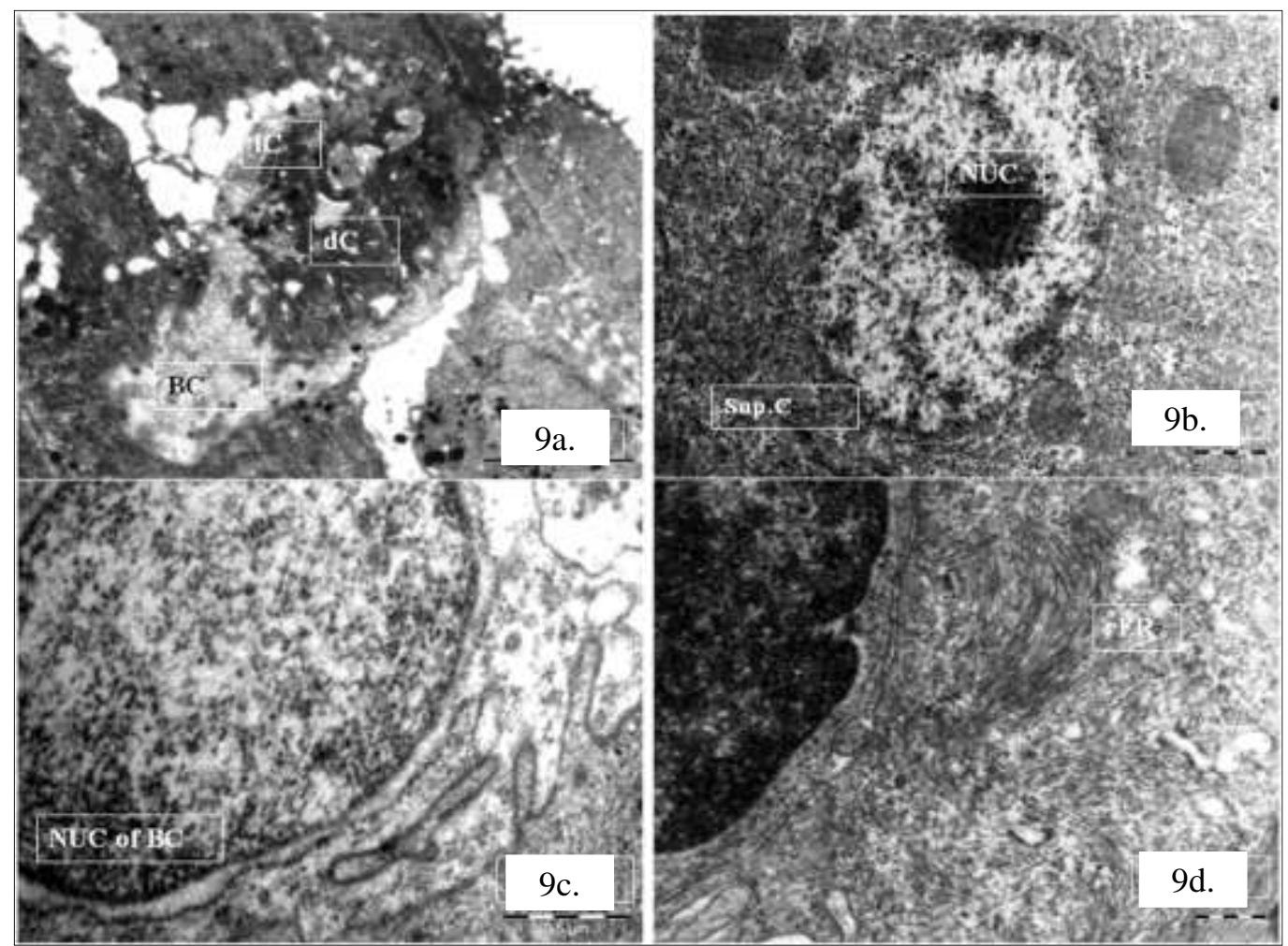

Fig 9(a): Transmission electron micrograph of lower lip of Clarias magur showing taste bud cells and marginal cells which are situated at the border of the taste buds in sensory epithelium. The supporting cells emit few microvilli covered with surface coat. (b) Transmission electron micrograph of lower lip of Clarias magur showing nucleus (NUC) of the supporting cells (Sup.C) and mucus cells (MC). (c) Transmission electron micrograph of lower lip of Clarias magur showing nucleus (NUC) of the basal cells (BC) and dense core vesicles. (d) Transmission electron micrograph of lower lip of Clarias magur showing cellular pattern of light receptor cells with abundant rER and electron dense secretory vesicles, clear vesicles in the receptor area.

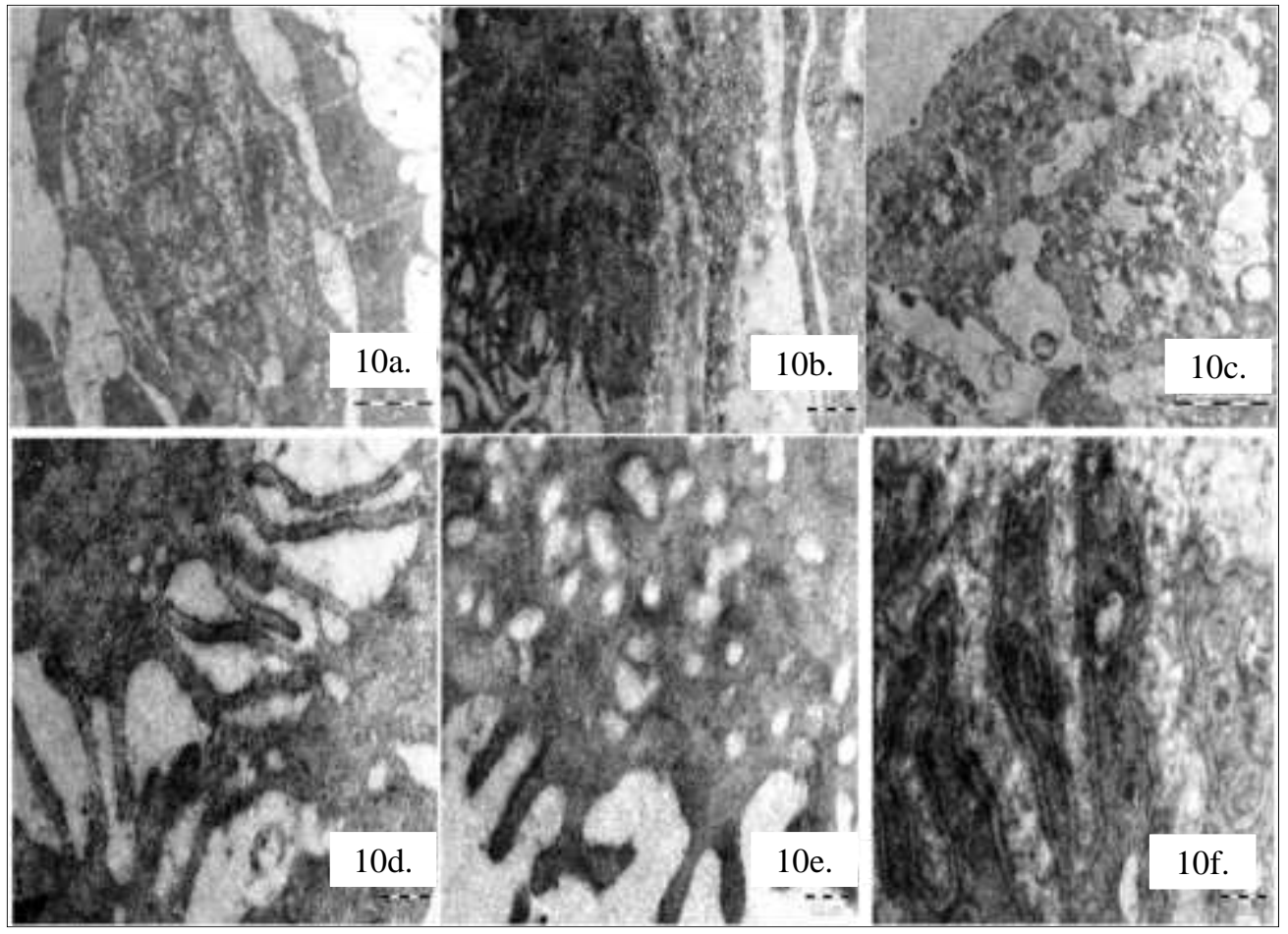

Fig 10(a): Transmission electron micrograph of lower lip of Clarias magur showing marginal cells which are situated at the border between sensory epithelium of taste buds and the unspecialized epithelium. (b) Transmission electron micrograph of lower lip of Clarias magur showing vertically oriented microtubules and profiles of smooth endoplasmic reticulum. (c) Transmission electron micrograph of lower lip of Clarias magur showing dense core vesicular cells. (d) Transmission electron micrograph of lower lip of Clarias magur showing cellular pattern of interdigitation in the functional area. (e) Transmission electron micrograph of lower lip of Clarias magur showing nerve endings below the interdigitation near the receptor area. (f) Transmission electron micrograph of lower lip of Clarias magur showing finger like projections between nerve filament and basal cells. 


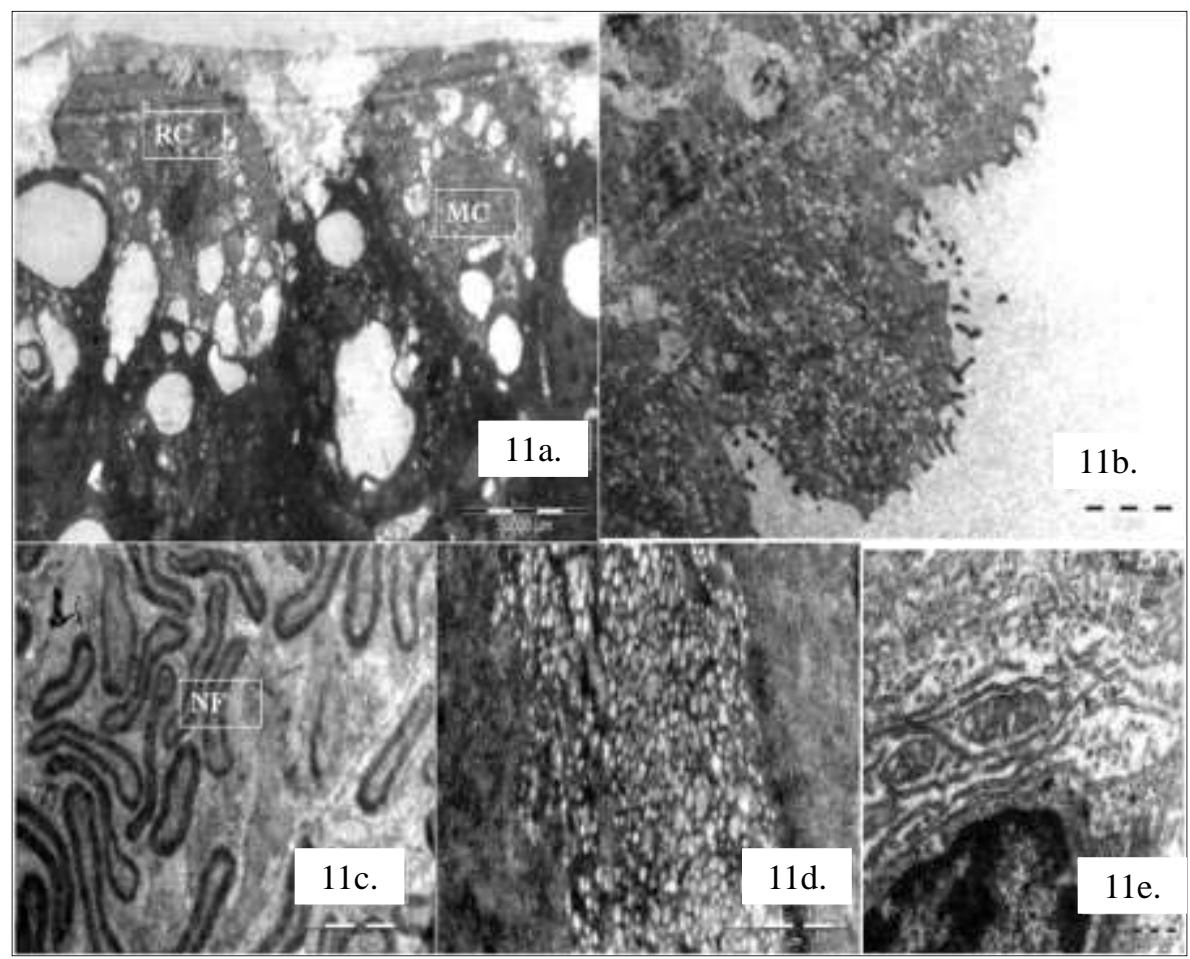

Fig 11(a): Transmission electron micrograph of barbel of Clarias magur showing linear arrangement of mucus cells. (b) Transmission electron micrograph of barbel of Clarias magur showing outer receptor area with microvilli. (c) Transmission electron micrograph of barbel of Clarias magur showing axonal characteristics of the myelinated nerve fibers. (d) Transmission electron micrograph of barbel of Clarias magur showing cellular pattern in the nerve endings ensheathed by cytoplasmic processes of receptor cells containing accumulation of clear vesicles. (e)

Transmission electron micrograph of barbel of Clarias magur showing prominent spindle shaped mitochondria with cristae in the sensory cells.

\section{Photo micrograph of transmission electron microscopy of Mystus tengra}

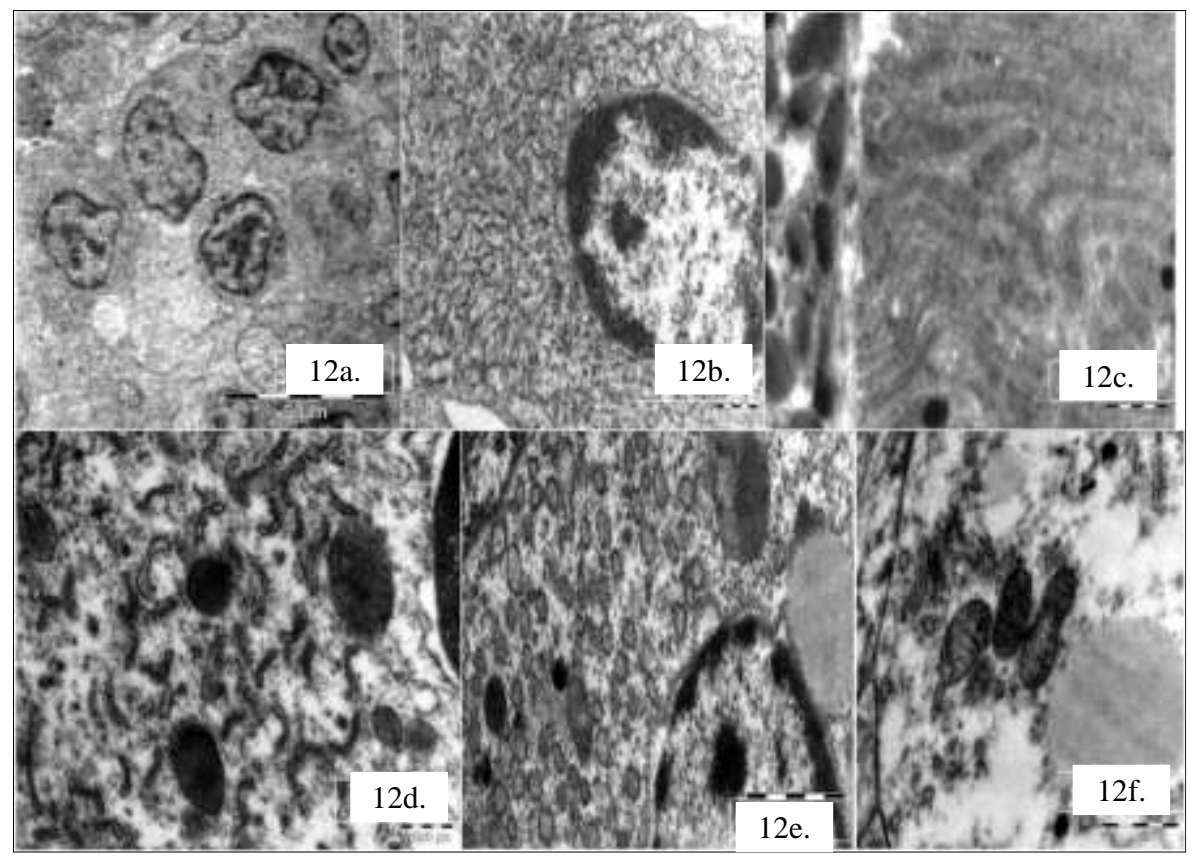

Fig 12(a): Transmission electron micrograph of upper lip of Mystus tengra showing apical portion of the receptor area. (b) Transmission electron micrograph of upper lip of Mystus tengra showing perinuclear characteristics of nucleus of light cell. (c) Transmission electron micrograph of upper lip of Mystus tengra packed tubuler mitochondria in the perinuclear position. (d) Transmission electron micrograph of

upper lip of Mystus tengra showing cellular pattern in mucus cell with huge parallelly arranged rER, ribosome and core vesicles. (e)

Transmission electron micrograph of upper lip of Mystus tengra showing rER, electron dense secretory vesicles and large nucleus with prominent nucleolus. (f) Transmission electron micrograph of upper lip of Mystus tengra showing parallelly arranged mitochondria around the nucleus. 


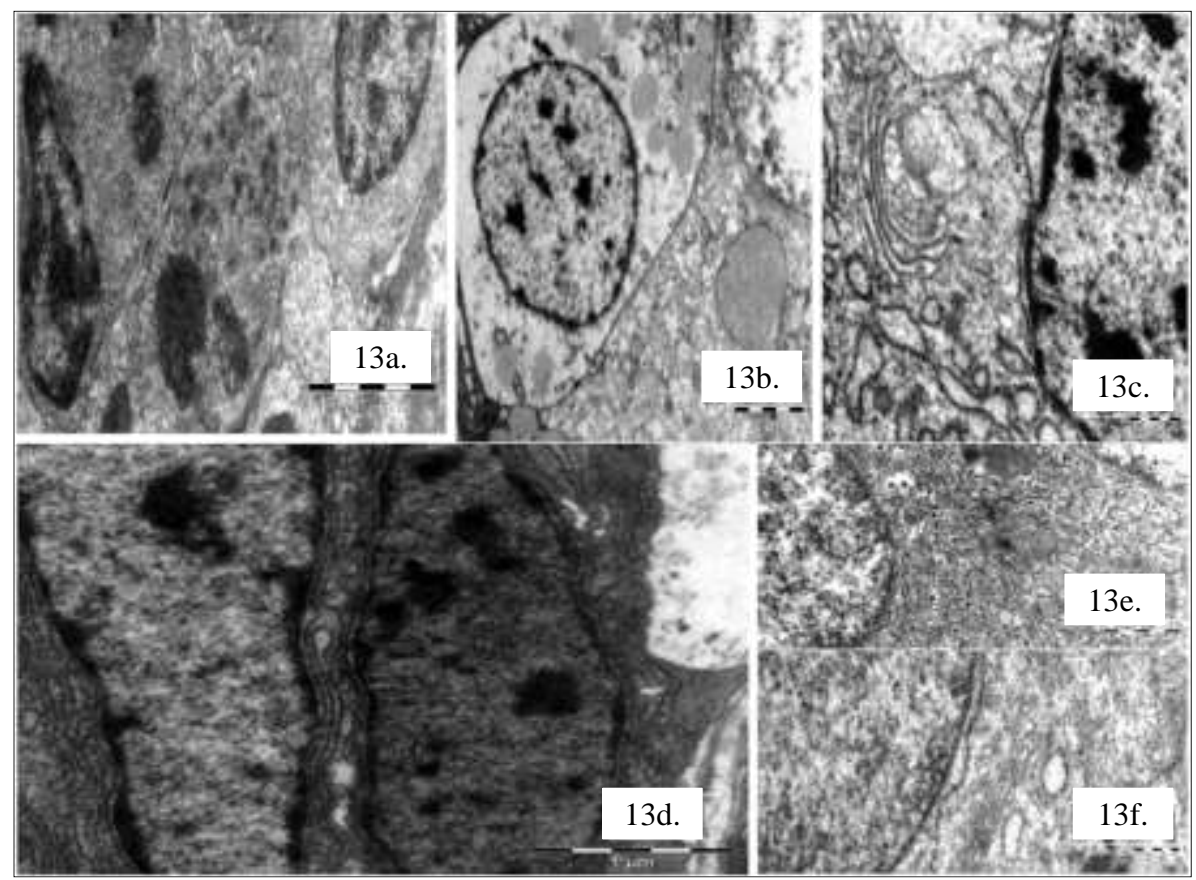

Fig 13(a): Transmission electron micrograph of lower lip of Mystus tengra showing mucus cells, dense core vesicular cells with sensory cells. (b) Transmission electron micrograph of lower lip of Mystus tengra showing nucleus of a mucus cells. (c) Transmission electron micrograph of lower lip of Mystus tengra showing nuclear characteristics of sustentacular cells. (d) Transmission electron micrograph of lower lip of Mystus tengra showing arrangement of light and dark cells. (e, f) Transmission electron micrograph of lower lip of Mystus tengra showing parallelly arranged rER and electron dense secretory vesicles at the periphery of the basal cells.

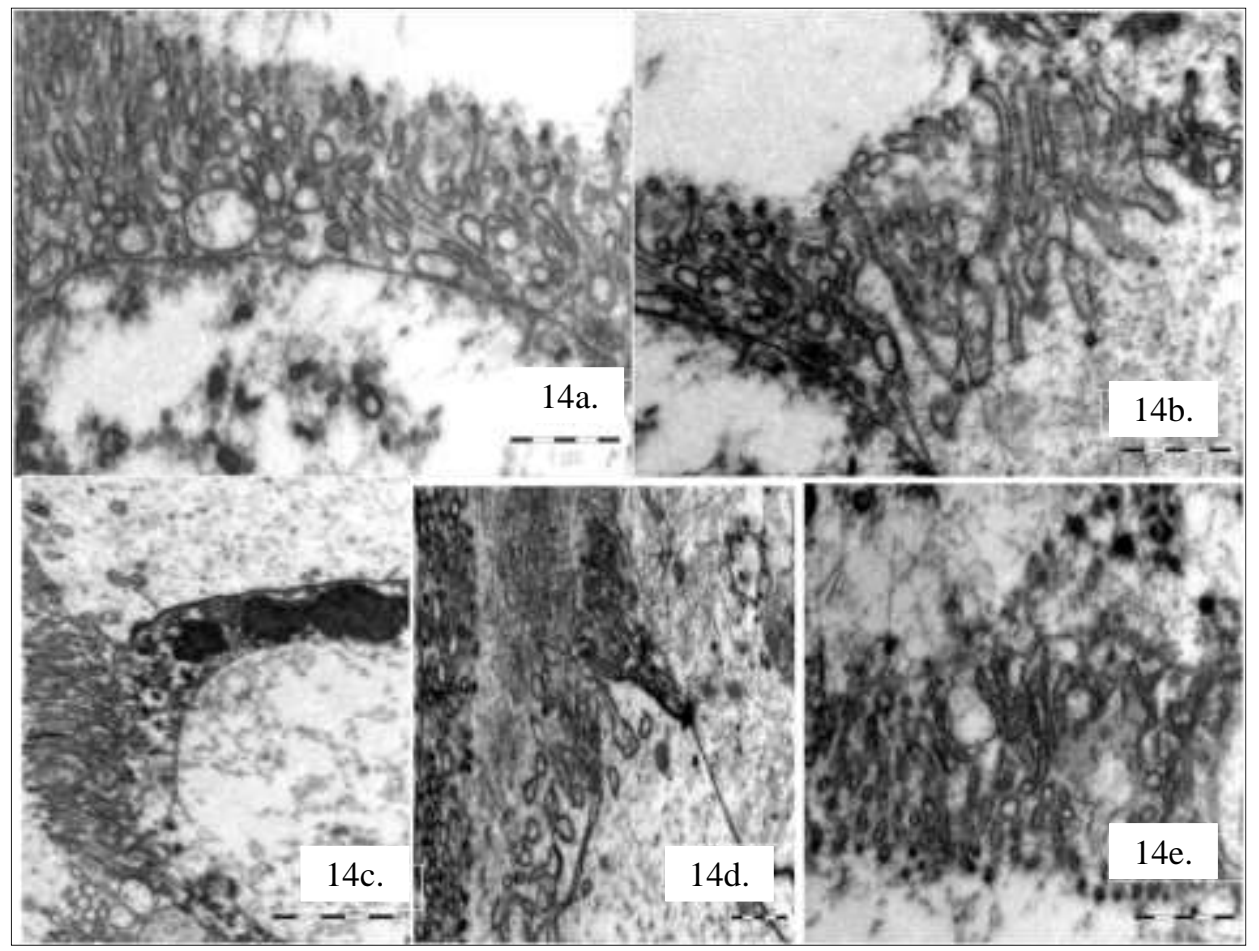

Fig 14(a): Transmission electron micrograph of barbel of Mystus tengra showing axonal characteristics in the synaptic region. (b) Transmission electron micrograph of barbel of Mystus tengra showing synaptic junction between the basal cells and nerve fibre. (c) Transmission electron micrograph of barbel of Mystus tengra showing cut section of the synaptic area. (d, e) Transmission electron micrograph of barbel of Mystus tengra showing cross section of axon of the myelinated nerve fibre in the synaptic region.

\section{Conclusion}

Scientists argue that the polymorphism and differential distribution of TBs detected in these local fishes are because of differences in their habitat and nourishment ${ }^{[45]}$. Though the selected species belongs to more or less same feeding ecology and territory, the distribution pattern as well as surface morphology of TBs are found to be very different. Thus, the differences in the appearance and arrangement of TBs with other accessory cells may be due to some intriguing factors on which the chemo sensation of lip and barbel architecture is dependent. These intriguing factors may be correlated with the ontogenetic adaptability and plasticity of the gustatory system in different species enjoying proximate distinguishable micro ecological needs. After consideration of this ontogenetic adaptability, an intriguing fact can be assumed that there may be a pathway by which vision and taste 
receptors cross-talk between them with help of some biomolecular entity. The polymorphism and differential distribution of fish TBs may provide indication to the hypothesis that morphologically different taste cells and its diverse distribution pattern may be related not only to the sense of taste but to neurobiology and developmental biology as well. Finally, it can be concluded that the cellular as well as morphological specializations of lips and barbels may be influenced by the mode of feeding behavior and the ecological condition in which fish live. It is conceivable that such an adaptation is indispensable to carry out the feeding function in the hostile environment for survival of the individuals and species.

\section{References}

1. Kasumyan AO, J Fish Biol. 2019;95:155-178.

2. Hara TJ, Olfaction and gustation in fish: an overview. Acta physiol scand 1994;152:207-217.

3. Hara TJ. Gustation. In: Zielinski B, Hara TJ (eds) Sensory systems neurosciences. Fish Physiol 2006;25:4596.

4. El Bakary NER. Morphology of the Buccal Cavity of Sea Bream (Sparus aurata) and Its Relation to the Type of Feeding Using Scanning Electron Microscopy. Global Veterinaria 2012;9(6):779-784.

5. Elsheikh EH, Nasr ES, Gamal AM, Ultrastructure and distribution of the taste buds in the buccal cavity in relation to the food and feeding habit of an herbivorous fish: Oreochromis niloticus. Tissue and cell 2012;44(3):164-16.

6. Tagliafierro G, Zaccone G, Morphology and immunochemistry of taste buds in bony fishes. In: Kapoor BG, Hara TJ (eds) Sensory biology of jawed fishes. IBH, New Delhi, 2335-345.

7. Fishelson L, Delarea Y, Zverdling A. Taste bud form and distribution on lips and in the oropharyngeal cavity of cardinal fish species (Apogonidae, Teleostei), with remarks on their dentition. J Morphol 2004;259:316-327.

8. Northcutt RG, Taste bud development in the channel catfish. J Comp Neurol 2005;482:1-16.

9. Northcutt RG. Taste buds: development and evolution. Brain Behav Evol 2004;64:198-206.

10. Finger TE Gustatory pathways in the bullhead catfish. I. Connections of the anterior ganglion. Journal of comparative neurology 1976;165:513-526.

11. Kasumyan AO. Gustatory reception and feeding behavior in fish. J. Ichthyol 1997;37:72-86.

12. Kiyohara SS, Yamashita, Kitoh J, Distribution of taste buds on the lips and inside the mouth in the minnow, Pseudorasbora parva. Physiol. Behav 1980;24:11431147.

13. Tripathi P, Mittal AK. Essence of Keratin in Lips and Associated Structures of a Freshwater Fish Puntius sophore in Relation to its Feeding Ecology: Histochemistry and Scanning Electron Microscope Investigation. Tissue and Cell 2010;42:223-233.

14. Pinky, Mittal S, Ojha J, Mittal AK. Scanning electron microscopic study of the structures associated with lips of an Indian hill stream fish Garra lamta (Cyrinidae, Cyriniformes) European Journal of Morphology 2004;40:161-169.

15. Tripathi P, Mittal AK. Diversity of lips and associated structures in fishes by sem. In: "scanning electron microscopy. (kazmiruk v. Ed.)". In tech. Pub. 2012, 147-
176.

16. Bloomquist R, Parnella NF, Phillipsa KA, Fowlera TE, Yuc TY, Sharpec PT et al. Coevolutionary patterning of teeth and taste buds 2015;112(44):E5954-E5962.

17. Neveen El, El Bakary SR, Morphological study of the asymmetrical buccal cavity of the flatfish common solea (Solea solea) and its relation to the type of feeding. Asian Pacific Journal of Tropical Biomedicine 2014;4(1):1317.

18. Viña E, Parisi V, Cabo R, Laurà R, López-Velasco S, López-Muñiz A et al. Acid-sensing ion channels (ASICs) in the taste buds of adult zebrafish. Neurosci. Lett 2013;536:35-40.

19. Ohkubo Y, Masubuchi M, Fujioka K, Tomita Y, Matsushita $\mathrm{T}$, Ohsuga $\mathrm{K}$ et al. Journal of Oral Biosciences 2005;47:77-82.

20. Dey S, Misra KK, Homechoudhuri S. Distribution of Gustatory System in the lips of Spotted Snakehead, Channa punctatus (Bloch 1793) and Spiny Eel, Mastacembelus pancalus (Hamilton 1822) from India. World Journal of Fish and Marine Sciences 2015;7(4):247-262.

21. Lev F, Delarea Y. Comparison of the oral cavity architecture in surgeon fishes (Acanthuridae, Teleostei), with emphasis on the taste buds and jaw "retention plates". Environ Biol Fish 2013;97:173-185.

22. Singh H, Bisht I. Comparative Study of Lips in Three Hill-Stream Fishes (Botia almorhae, Homaloptera brucei and Schizothorax richardsonii) of Kumaun Region: A SEM Investigation. International Journal of Science and Research 2014;3(5):716-721.

23. McCormick MI, Development and changes at settlement in the barbel structure of the reef fish, Upeneus tragula (Mullidae). Envorin. Biol. Fishes 1993;37:269-282.

24. Abou-ZAID DFA, A comparative study of the distribution and morphology of the external taste buds in the Siluroids fishes, Malupterus Electricus And Clarias Lazera. International Journal of Advanced Research 2014;2(5):1083-1095.

25. In-Seok $\mathrm{P}$, Chi-Hong $\mathrm{K}$, Choi JW. Histological Observations and Regeneration of Barbels in Juveniles of the Chinese Longsnout Catfish Leiocassis longirostris. Fisheries Aquatic Sciences 2012;15(4):299-303.

26. Yashpal M, Kumari U, Mittal S, Mittal AK. Surface architecture of the mouth cavity of a carnivorous fish Rita rita (Hamilton, 1822) (Siluriformes, Bagridae). Belg. J. Zool. 2006;136(2):155-162.

27. Ahmed ATA, Rahman MM, Mustafa G, Sanaullah MA. Comparative study of food and feeding habits of three of fish from beel Mahmud Faridpur. Bangladesh Journal of Zoology 1993;21:11-21.

28. Boudriot F, Reutter K. Ultrastructure of the taste buds in the blind cave fish Astyanax jordani ("Anoptichthys") and the sighted river fish Astyanax mexicanus (Teleostei, Characinidae). J. Comp. Neurol 2011;434:428-444.

29. Gupta S, Banerjee S. Food and feeding habit of a freshwater catfish, Mystus tengara (Siluriformes: Bagridae). Journal of Ichthyology 2014;54(9):742-748.

30. Harvey R, Batty RS. Cutaneous taste buds in gadoid fishes. J. Fish Biol 2004;60(3):783-792.

31. Aguirre H, Lombarta A. Distribution pattern of taste buds along hyoidal barbels of Mulus barbatus and $\mathrm{M}$. surmuletus. Brain Beha. Evol 200;56:323-329.

32. Grover-Johnson N, Farbman AI. Fine structure of taste 
buds in the barbell of the Catfish, Ictalurus punctatus. Cell Tissue Research 1976;169:395-403.

33. Zuwala K, Jakubowski M. Light and electron (SEM, TEM) microscopy of taste buds in the tench Tinca tinca (Pisces: Cyprinidae). Acta Zool. Copenh 1993;74:277282.

34. Gon O, Fishelson L, Delarea Y. Comparative morphology of the oropharyngeal cavity in clinid fishes (Perciformes: Clinidae), with particular attention to the form, number and distribution of taste buds and dentition. Am J Mar Sci 2010;29:283-298.

35. Reutter K, Hansen A. Subtypes of light and dark elongated taste bud cells in fishes. In: Reutter K, Kapoor BG (eds) Fish chemosenses. Science Publishers, Enfield, 2015, 211-230.

36. Jakubowski M, Whitear M, Comparative morphology and cytology of taste buds in teleosts. Z. Mikrosk-Anat Forsch. Leipzig 1990;104:529-560.

37. Moriyama K, Watanabe S, Iida M, Sahara N. Plate-like permanent dental laminae of upper jaw dentition in adult gobiid fish, Sicyopterus japonicus. Cell Tissue Res 2010;340(1):189-200.

38. Agrawal N, Mittal AK. Structural organisation and histochemistry of the epithelia of lips and associated structures of a carp - Cirrhina mrigala. Can. J. Zool 1992;70:71-78.

39. Sane SP, McHenry MJ. The biomechanics of sensory organs. Integrative and Comparative Biology 2009, 1-16.

40. Ghattas SM, Yanai T. Light microscopical study on the skin of eel (Anguilla Anguilla). World Journal of Fish and Marine Sciences 2010;2(3):152-161.

41. Zaccone G, Kapoor BG, Fasulo S, Ainis L, Structural, histochemical and functional aspects of the epidermis of fishes. Adv. Mar. Biol 2001;40:253-348.

42. Halbgewachs CF, Marchant TA, Kusch RC, Chivers DP. Epidermal club cells and the innate immune system of minnows. Biological Journal of Linnean Society 2009;98:891-897.

43. Ahmed SAH, Imam AA. Skin Characteristics and Organization of the Air-breathing Fish, Alticus kirkii (Günther, 1868) along Different Body Regions. Journal of Biological Sciences 2011;11:466-474.

44. Ikpegbu E, Ezearsor DN, Nlebedum UC, Nwogu C, Nnadozie O, Agbakwuru I. Histological study of the pharyngeal pad of the African catfish (Clarias gariepinus Burchell, 1822). Animal Research International 2012;9(3):1613-1618.

45. Fishelson L. Dentition and taste buds in Blennies. In: The Biology of Blennies (Patzner R, Gonçalves E.J, Hastings P.A. \& Kapoor B.G., eds), Enfield (NH): Science Publishers 2009, 163-185. 